\title{
Gymnosperms from the Early Cretaceous Crato Formation (Brazil). II. Cheirolepidiaceae
}

\author{
Lutz Kunzmann*, 1, Barbara A. R. Mohr², Mary E. C. Bernardes-de-Oliveira ${ }^{3}$ \& Volker Wilde ${ }^{4}$ \\ ${ }^{1}$ Museum für Mineralogie und Geologie der Staatlichen Naturhistorischen Sammlungen Dresden, Königsbrücker Landstraße 159, \\ D-01109 Dresden, Germany \\ 2 Museum für Naturkunde der Humboldt-Universität Berlin, Invalidenstraße 43, D-10115 Berlin, Germany \\ ${ }^{3}$ CEPPE - Post-Graduation, Research and Specialization Center of the University Guarulhos, Praça Tereza Cristina 1, \\ 07023-070, Guarulhos (SP), Brazil; and Institute of Geosciences, University of São Paulo, Rua do Lago 562, \\ Cidade Universitária, 05508-080, São Paulo (SP), Brazil \\ ${ }^{4}$ Forschungsinstitut und Naturmuseum Senckenberg, Sektion Paläobotanik, Senckenberganlage 25, \\ D-60325 Frankfurt am Main, Germany
}

Received 21 December 2005, accepted 7 March 2006

Published online 17 July 2006

With 5 figures and 1 table

Key words: fossil conifers, Cheirolepidiaceae, Frenelopsis, Tomaxellia, leaf epidermis, Early Cretaceous, Aptian, Crato Formation, Brazil.

\begin{abstract}
Conifers are common in the Early Cretaceous Crato flora. Sterile foliage shoots of several morphotypes occur. Good preservation of several of these specimens allows detailed morphological and anatomical studies. Based on these characters, two taxa of Cheirolepidiaceae, Tomaxellia biforme and Frenelopsis sp., are identified. The palaeogeographic distribution of the genus Tomaxellia currently extends from southern South America northwards to the palaeoequatorial region. The morphological and anatomical characters of both taxa might be interpreted as adaptations to a warm and temporarily dry palaeoclimate, however their habitat can not be reconstructed yet, due to scarcity of the remains.
\end{abstract}

Schlüsselwörter: Fossile Koniferen, Cheirolepidiaceae, Frenelopsis, Tomaxellia, Blattepidermis, Untere Kreide, Apt, Crato-Formation, Brasilien.

\section{Zusammenfassung}

Koniferen stellen eine wesentliche Komponente der unterkretazischen Crato-Flora dar. Es kommen sterile beblätterte Zweige verschiedener Morphotypen vor. Die gute Erhaltung einiger dieser Fossilreste lässt detaillierte morphologisch-anatomische Untersuchungen zu. Auf der Basis solcher Merkmale wurden zwei Taxa der Cheirolepidiaceae, Tomaxellia biforme und Frenelopsis sp., identifiziert. Das Areal der Gattung Tomaxellia wird damit vom südlichen Südamerika nordwärts, in die paläoäquatoriale Region erweitert. Morphologische und anatomische Merkmale beider Taxa können als Anpassungserscheinungen an ein warmes und periodisch trockenes Paläoklima interpretiert werden. Auf Grund des seltenen Vorkommens solcher Fossilreste können noch keine Angaben zu ihrem ehemaligen Habitat gemacht werden.

(C) 2006 WILEY-VCH Verlag GmbH \& Co. KGaA, Weinheim

\section{Introduction}

Remains of conifers assigned to the extinct family Cheirolepidiaceae Takhtajan ex Doludenko,
1978 were more or less distributed worldwide during the Mesozoic, except for very high latitudes where macroremains and pollen only rarely occur (e.g. Cantrill \& Falcon Lang 2001;

\footnotetext{
* e-mail: lutz.kunzmann@snsd.smwk.sachsen.de
} 
Falcon Lang \& Cantrill 2000; Mohr \& Gee 1992). During Jurassic and Cretaceous the maximum diversity and abundance of this conifer family was certainly in southern Laurasia and northern Gondwana. High percentages and large morphological variety of pollen in the respective pollen spectra (Spicer et al. 1994) indicate that these conifers occupied a variety of ecological niches (Watson 1988; Axsmith \& Jacobs 2005).

The general morphology of cheirolepidiaceous pollen named Classopollis Pflug, 1953 (Traverse 2004) - older synonyms are Circulina, Corollina and Gliscopollis - is the most conspicuous character of this family, while growth habit, morphology and size of leaves and cones as well as cuticle morphology vary substantially. Cheirolepidiaceae have been recognised from the Triassic through to the Late Cretaceous, possibly until the Maastrichtian (Van der Ham et al. 2003). The genera Brachyphyllum Lindley \& Hutton, 1836 emend. Harris, 1979 (pro parte), Cupressinocladus Seward, 1919 (pro parte), Frenelopsis Schenk, 1869, Pseudofrenelopsis Nathorst, 1893 emend. Srinivasan, 1995, Pagiophyllum Heer, 1881 (pro parte), Tarphyderma Archangelsky \& Taylor, 1986 and Tomaxellia Archangelsky, 1963 are Cretaceous members of this family. Additional Cretaceous taxa potentially belonging to the Cheirolepidiaceae are Androvettia Hollick \& Jeffrey, 1909 and Glenrosa Watson \& Fisher, 1984 (Watson 1988).

Studies on cheirolepidiaceous conifers focussed first on material from the Northern Hemisphere (e.g. Jung 1968; Harris 1979; Alvin 1982; Francis 1983; Axsmith \& Jacobs, 2005). During the $20^{\text {th }}$ Century South and Central American fossil conifers were studied as well (among others Spegazzini 1924; Calder 1953; Archangelsky 1963, 1966, 1968; Archangelsky \& Gamerro 1968). Patagonian Mesozoic conifer remains comprise, besides Podocarpaceae Endlicher, 1847, and Araucariaceae Henkel \& Hochstätter, 1865 , also several taxa of Cheirolepidiaceae. The latter include vegetative parts with preserved cuticles and various strobili (e.g. Archangelsky 1994; Calder 1953), for instance vegetative and fertile parts of Tomaxellia degiustoi (Archangelsky 1963) and T. biforme (Archangelsky 1966, 1968), and vegetative shoots of Tarphyderma punctata (Archangelsky \& Taylor 1986, 1991).

Early Cretaceous floras from low latitudes of South America are less well known (see below). Reports exist only from Brazil and Colombia. Conifers have been published from the floras of the Sergipe-Alagoas Basin, Brazil (Linder Dutra et al. 2002) and from the Araripe Basin, Brazil (Duarte 1985, 1993; Kunzmann et al. 2004; this paper). From the Leiva region, Colombia, several species of Cupressinocladus, Brachyphyllum, Pagiophyllum and Podozamites Braun, 1843 have been described and figured (Pons 1988; Van Waveren et al. 2002). However, their botanical affinity is not clear since cuticles are not preserved.

This study is based on specimens of cheirolepidiaceous affinity from the late Aptian Crato Formation of Brazil and thus adds information on the distribution of cheirolepidiaceous conifers of Southern Hemisphere low latitudes. Descriptions of epidermal characters are given, and the respective structures are interpreted palaeoecologically.

\section{Location and stratigraphy}

The plant fossils were collected from open cast pits several kilometers south of the town of Nova Olinda, between Nova Olinda and Santana do Cariri exposing the Nova Olinda Member of the Crato Formation of the Araripe Basin, in northeastern Brazil. The Araripe Basin contains Late Jurassic to late Early Cretaceous sediments that were deposited during the early opening of the Atlantic Ocean. The Crato Formation is the lowermost part of the Santana Group, and based on palynological data, is probably late Aptian to earliest Albian in age (Arai et al. 2001; Doyle 1992; Lima 1978; Neumann \& Cabrera 1999; Pons et al. 1996). For more detailed geographical and geological information see Regali (1989), Maisey (1991), Martill et al. (1993), Mohr \& Bernardes-de-Oliveira (2004).

\section{Material and Methods}

The yellowish to light greyish brown bedded limestone (Plattenkalk) delivers a wide array of fossils, including invertebrates and vertebrates, as well as a diverse flora. The plant fossils are variably preserved. Conifer remains constitute a relatively large part of the flora. They are mainly represented by sterile leafy shoots, reproductive material is less frequent.

As it is also true for the other components of the flora, most of the coniferalean remains are preserved as impressions with or without a thin layer of iron oxide which replaced the original organic matter. Rare specimens show a fully and three-dimensional replacement by iron oxide. Nevertheless, some of these specimens show the cellular structure of the leaf epidermis (Fig. 2C).

The fossils were studied under a Leica MZ APO Microscope equipped with a camera lucida and a digital camera DFC 320. Some of the photographs were taken with a Nikon digital camera and a $60 \mathrm{~mm}$ Nikkor macro-objective. For SEM studies, small pieces of the iron oxide were removed from the specimen, directly mounted on stubs and sputtered 
for 4 minutes with $\mathrm{Au} / \mathrm{Pd}$. The SEM-photographs were taken on a LEO 1450VP SEM. Cellular details of the leaf epidermis were partly visible also under the LM. In addition, we tried to obtain leaf cuticles. Small parts of lateral shoots were removed from the specimen and prepared with Schultze solution. However, this method did not prove to be successful.

The material used for this paper is housed in the palaeobotanical collections of the Museum für Naturkunde Berlin, Germany (= MfN PB) and the Palaeobotanical Section of the Forschungsinstitut Senckenberg in Frankfurt/M., Germany (= SM.B).

\section{The Flora of the Araripe Basin}

Sporomorphs, as well as macroscopic plant remains are known from the late Aptian Crato and the early Albian Santana Formation. The stratigraphical and biological aspects of the dispersed sporomorphs have been studied intensely (e. g. Arai et al. 2001; Lima 1978; Lima 1979; Osborn et al. 1993; Pons et al. 1996) and show that a variety of gymnosperms, including cycadophytes, gnetophytes and conifers, and angiosperms must have grown relatively close to the site of deposition.

The Crato macroflora consists of a diverse assemblage of pteridophytes, including schizaeaceous ferns (e.g. Bernardes-de-Oliveira et al. 1999) and Isoetaceae (e.g. Bernardes-de-Oliveira et al. 2003) and various gymnosperms such as ephedroid and welwitschioid gnetophytes (Rydin et al. 2003; Mohr et al. 2004; Dilcher et al. 2005), conifers (Duarte 1985, 1993; Kunzmann et al. 2004; this paper), and a variety of angiosperms (Barreto et al. 2000; Mohr \& Friis 2000; Mohr \& Bernardes-de-Oliveira 2004). In total, about 70-80 taxa have been recognized, of which about 30 are putative angiosperms, mostly magnoliid dicotyledons (Leme et al. 2005; Mohr \& Eklund 2003; Mohr \& Bernardes-de-Oliveira 2004).

The macroflora of the Santana Formation (Romualdo Member) is less well known, because of relatively rare specimens in nodules that mostly contain vertebrate fossils (fish). However, sometimes such nodules contain various remains of conifers, such as vegetative shoots of frenelopsid conifers (Bernardes-de-Oliveira et al. 2005), Brachyphyllum spp., and cones (Crane, in Maisey 1991; Duarte 1985).

\section{The conifers of the Araripe Basin}

The conifers of the Crato and Santana Formations were previously known mainly from the pollen record, and secondarily from macrofossils
(Lima, 1979; Duarte 1985, 1993; Bernardes-deOliveira et al. 1993; Kunzmann et al. 2004; Martill et al. 2005).

Araucariaceae are represented by pollen of the Araucariacites-type (Lima 1979) and by female cones (cf. Araucaria sp.; Kunzmann et al. 2004), as well as araucarioid cone scales (Martill et al. 1993) and vegetative shoots of Brachyphyllum obesum Heer, 1881 (Kunzmann et al. 2004). Fossil amber in connection with araucarian remains has been described lately (Martill et al. 2005). Leafy shoots of Lindleycladus Harris, 1979 (incertae sedis vel Araucariaceae) may perhaps also belong to the Araucariaceae (Kunzmann et al. 2004). Lima (1979) recognised Podocarpaceae by its pollen.

The Cheirolepidiaceae seem to be diverse, but so far only dispersed pollen grains have been described (Lima 1979). Classopollis alexi Burger, C. torosus (Reissinger) Couper, C. brasiliensis (Herngreen), cf. C. infrareticulatus Volkheimer, Circulina parva Brenner, C. minima (Herngreen) Lima, and C. meyeriana Klaus certainly represent various biological species. Lima's (1979) Classopollis species are very similar in size and shape to those in situ described from Classostrobus
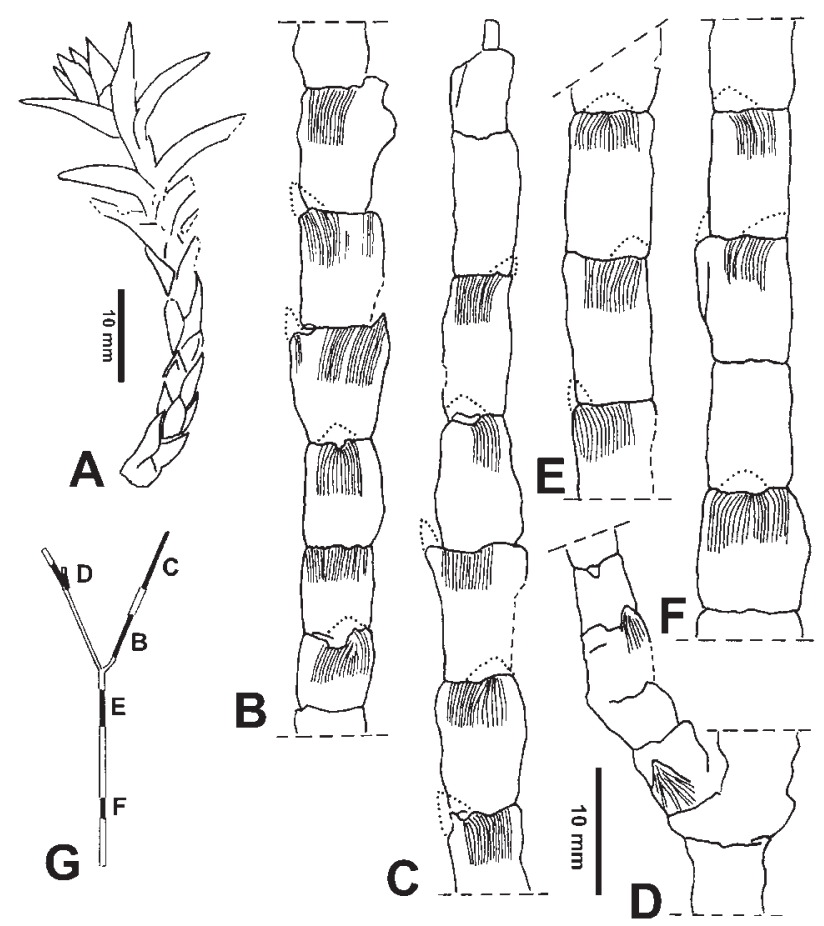

Fig. 1. Camera lucida drawings of selected specimens. A - Tomaxellia biforme Archangelsky, 1963, leafy shoot with two leaf morphotypes, MfN PB 1998/484; B-G - Frenelopsis sp., leafy shoot, SM.B 16486; B-F - different sections of the shoot, striation on the segment surfaces only figured in the apical parts of the segments to demonstrate curved striae below the free parts of the leaves (leaftips), dotted lines = abraded leaftips; $\mathbf{G}$ - simplified figure of the shoot, full black parts indicate the position of sections B-F. 
comptonensis Alvin et al., 1978 (Axsmith et al. 2004) representing male cones associated with vegetative shoots of Pseudofrenelopsis.

Although the pollen record of Cheirolepidiaceae in the Crato flora is known, vegetative remains and male and female cones have not been described so far. It was merely assumed, that the Brachyphyllum material (B. castilhoi Duarte 1985) partly might belong to the family (e.g. Duarte 1985; Crane in Maisey 1991; Kunzmann et al. 2004).

\section{Systematic descriptions}

Class Coniferopsida (Endlicher, 1847)

Family Cheirolepidiaceae Takhtajan ex Doludenko, 1978

Tomaxellia Archangelsky, 1963 emend. Archangelsky, 1966

\section{Tomaxellia biforme Archangelsky, 1966}

Figs $1 \mathrm{~A}, 2$

1966 Tomaxellia biforme Archangelsky: 291.

1968 Tomaxellia biforme. - Archangelsky: 153-165, pl.1-4, textfigs 1-2; (fertile and sterile organs).

1988 Tomaxellia biforme. - Watson: 415, figs 9.1, 9.22.

Material. MfN PB 1998/484 with preparation specimens MfN PB SEM 1998/484-1, 2, 3; MfN PB 2000/1034.

Description. Two ultimate order branchlets are preserved (Fig. 2A, G). Especially the specimen MfN PB 1998/484, a heterophyllous branch of $60 \mathrm{~mm}$ length, shows the typical characters of Tomaxellia biforme. Leaves are arranged in a simple helix. Short leaves occur basally, longer leaves apically, and at the top an opened bud with longer leaves is visible (Fig. 2B). All leaves appear to have been fleshy.

Short leaves are of the Brachyphyllum morphotype sensu Harris (1979) and show the following features: squamiform, leaf base decurrent, free part of the leaf adpressed, with an acute-obtuse apex. The leaf blade is semicircular to triangular in cross section and abaxially keeled. There is a continuous transition from short to long leaves. Leaves are 5-18 $\mathrm{mm}$ long and 3-3.5 $\mathrm{mm}$ wide.

Long leaves are of the Pagiophyllum morphotype sensu Harris (1979). The basal part is decurrent; the free part spreading, arising at $50^{\circ}-70^{\circ}$ from the axis, typically slightly recurved, narrow ovate to narrow elliptical in shape and scarcely narrowing at the base, tapering towards an acu- minate apex. The leaf blade is semicircular in cross section, with a convex abaxial side, slightly keeled.

Most of the organic matter is replaced by iron oxide, but some of the cellular structure of the leaf epidermis is still visible. There are slightly sunken parallel grooves on the abaxial side of the longer leaves that might represent stomatal rows. Under SEM, several apices of the youngest long leaves show details of the abaxial epidermis (Fig. 2C-E).

Ordinary epidermal cells are elongated and rectangular in shape with straight or slightly curved anticlinal walls, $20-70 \mu \mathrm{m}$ long and $12-15 \mu \mathrm{m}$ wide. They are arranged in simple longitudinal files.

There are only a few monocyclic stomata near the apex (Fig. 2C), in the median part of the apex they are arranged in files (Fig. 2F). The orientation of stomatal pori is rarely visible, in these cases it is longitudinal to the leaf axis. The outer epidermal surface shows a ring of 4 to 6 slightly elevated subsidiary cells (Florin ring; Fig. 2D). The ring of subsidiaries is $65-70 \mu \mathrm{m}$ long and $50-60 \mu \mathrm{m}$ wide. There are 2 polar, slightly elongated subsidiaries (Fig. 2E). Stomatal pits are rounded to oval, $\sim 25 \mu \mathrm{m}$ long and 13-15 $\mu \mathrm{m}$ wide, the guard cells are moderately sunken. No papillae have been found. Adaxial side unknown.

Discussion. Among all conifers from the Early Cretaceous of South America, only Tomaxellia biforme shows a characteristic heterophylly with two distinct leaf morphotypes (Archangelsky 1966). Although the leaf epidermis of the Crato material is poorly known, it supports the determination as well. SEM photographs of T. biforme were published by Watson (1988: figs 9.22C-F). They clearly show a nonpapillate epidermis and nonpapillate stomata with a Florin ring. The features of our material seem to fit the characters described by Watson (1988) and thus justify a specific determination. The Crato material is distinguished from T. degiustoi Archangelsky, 1963 by its heterophyllous shoots.

Palae obiogeography. The genus Tomaxellia is known only from the Early Cretaceous of South America (Archangelsky 1966; Watson 1988). The poorly known type species, T. degiustoi Archangelsky, 1963 and the well known species T. biforme Archangelsky, 1966 have previously been reported only from the Ticó flora in the Santa Cruz Province in Argentina (Watson 1988). Now, the area of T. biforme is extended northwards to significantly lower palaeolatitudes. 


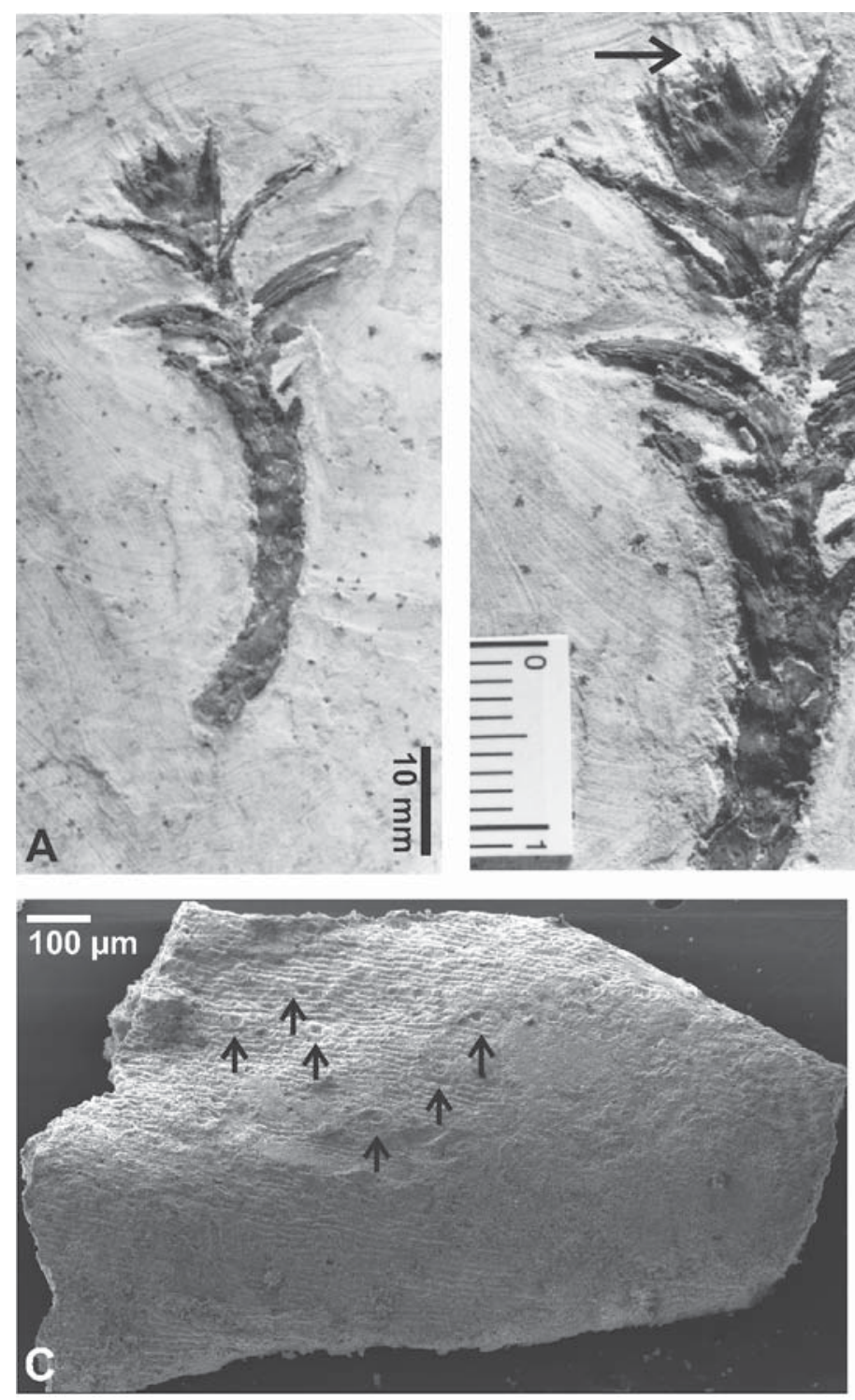

B
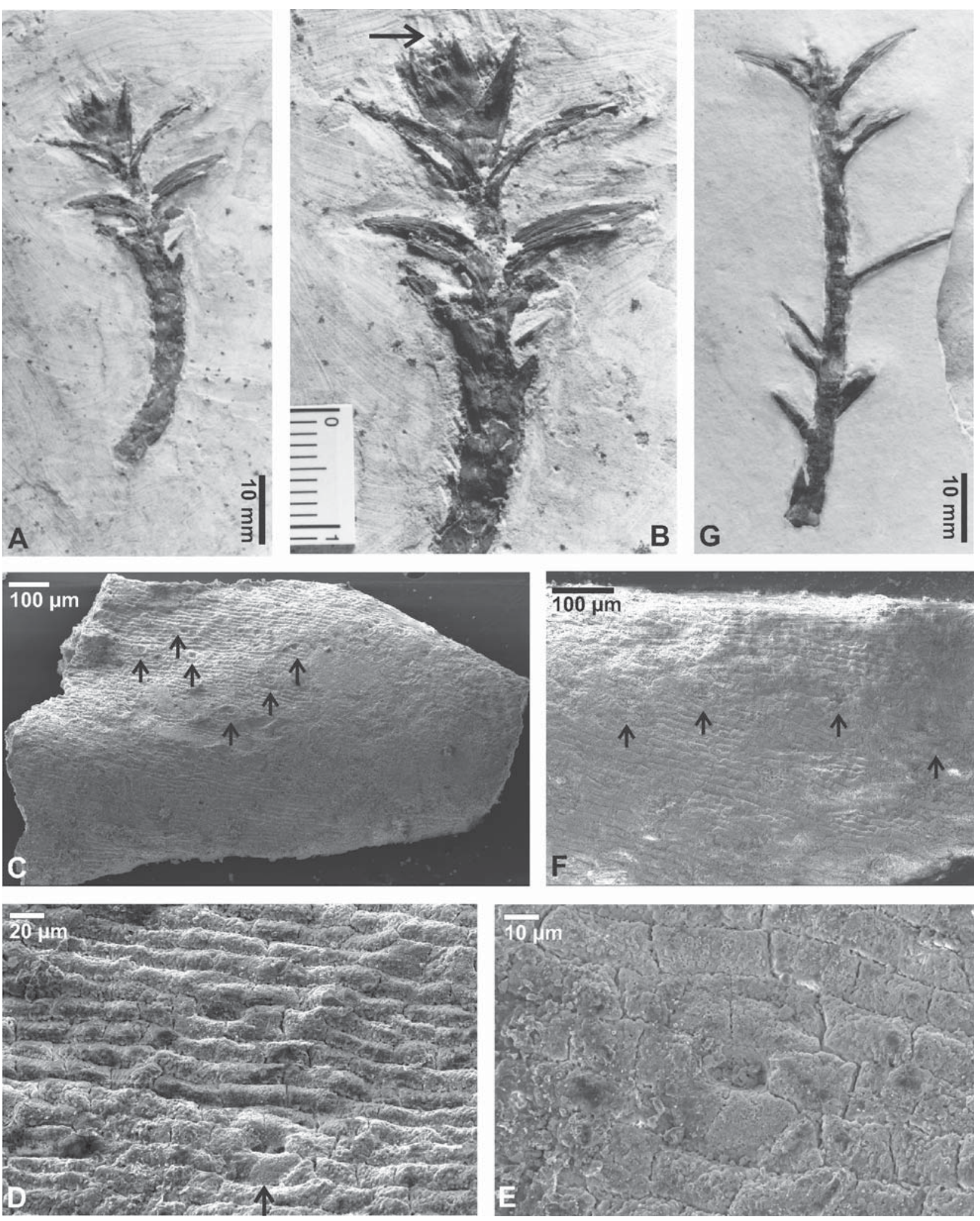

Fig. 2. Tomaxellia biforme Archangelsky, 1963. A-F - leafy shoot, MfN PB 1998/484; A - leafy shoot with two leaf morphotypes; B - apical part of the shoot, arrow indicates the position from where material for SEM studies was removed; C-E - abaxial epidermis by SEM, MfN PB 1998/484-1; C - leaf apex with few stomata (arrows); D - detail of C: stomata with Florin rings, arrow indicate stoma figured in E; E - detail of D: stoma with 6 subsidiary cells, polar subsidiaries slightly elongated, vertical view; F-epidermis by SEM, ordinary epidermis cells and stomata (arrows) partly destroyed, MfN PB 1998/484-3; G - leafy shoot, MfN PB 2000/1034. 

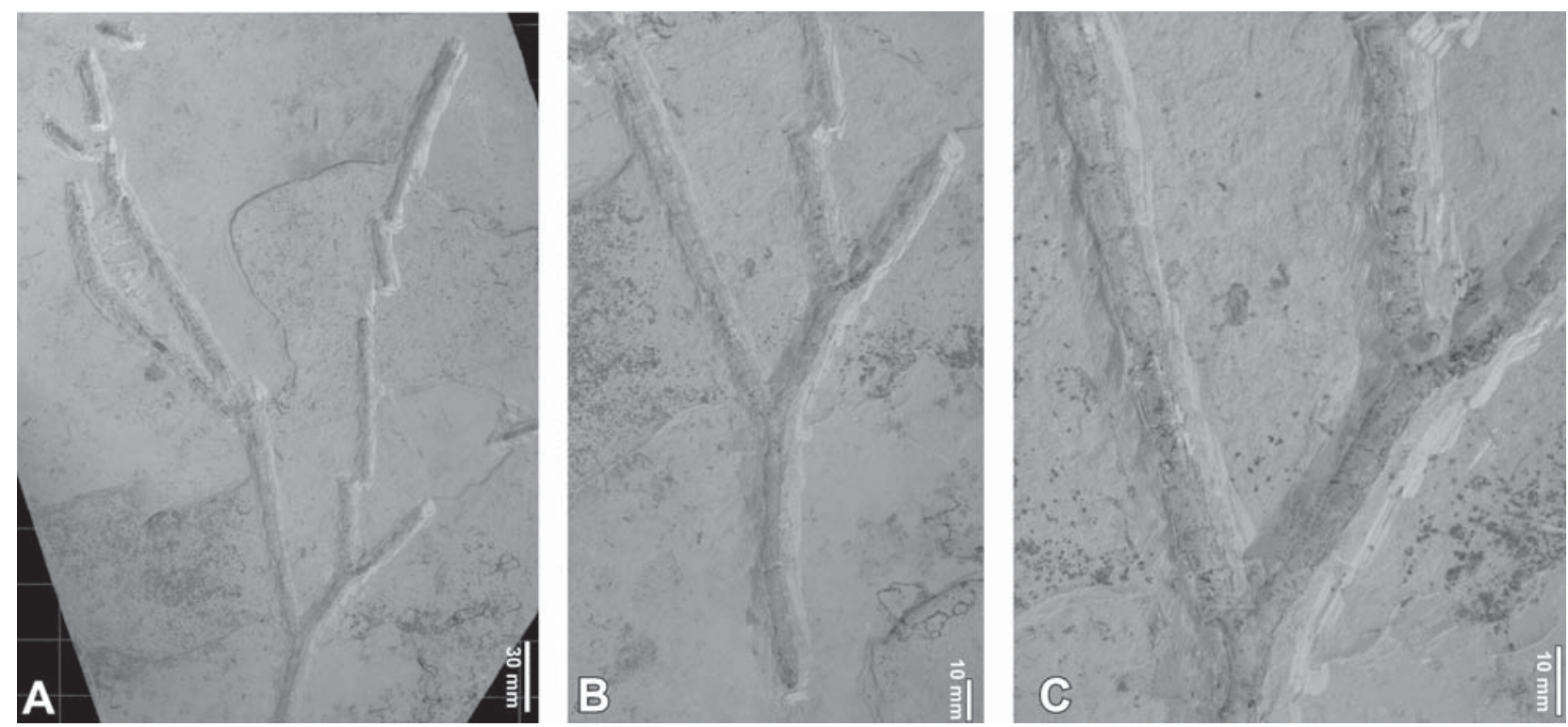

Fig. 3. Frenelopsis sp., leafy shoot, SM.B 16447; A - complete specimen; B-C - details of A.

Frenelopsis Schenk, 1869 emend. Watson, 1977

\section{Frenelopsis sp.}

Figs $1 \mathrm{~B}-\mathrm{G}, 3-5$

Material. SM.B 16447, SM.B. 16486, MfN PB 1999/390.

Description. Three specimens are available for this study. One is an impression with partly preserved epidermal characters (SM.B 16447, Fig. 3). In a second specimen the organic matter is replaced by iron oxide, partly with epidermal characters recognisable (SM.B 16486, Fig. 4). The third specimen is a poorly preserved impression (MfN PB.1999/390).

Shoot morphology: The large $(340 \mathrm{~mm}$ and $410 \mathrm{~mm}$ long), probably caduceous shoots are sparsely branched, the branchlets are aligned in one plane. Axes are branching almost dichotomously, but not completely symmetrical, the angle between two branchlets amounts $\sim 25^{\circ}$. The shoot of specimen SM.B 16447 is branching in three orders; the branchlets between two branching points are $35-150 \mathrm{~mm}$ long (Fig. 3A). Segmented shoots bearing whorls of 1 or 2 laterally fused squamiform leaves. The free part of a single leaf is triangular in shape, adpressed and has an acute apex; the free part is $1.5-2.0 \mathrm{~mm}$ long and broader than long, (Figs 1D, 5A-B).

In several of the branchlet's segments an opposite arrangement of two free leaf tips is observed (Fig. 5A), while other segments show only one leaf tip, which is not attached at an angle of $90^{\circ}$ to those above or below (Fig. 1C). In several cases a decussate arrangement occurs (e.g., Fig. 1B, F). Because the specimen is not diagene- tically flattened this leaf arrangement reflects the original phyllotaxis. If the leaf tips are not preserved or broken, a dense longitudinal striation on the segmental surfaces shows the former position of such leaf tips (Fig. 5C). There is a remarkable curvature of the parallel striae in the apical part of the segment before running into the free leaf tips (Fig. 1B-F). Otherwise the striae are running straight to the upper margin of the segment. Free parts of the leaves continue as a smooth cylindrical segment without sutures ("internodes" sensu Watson 1988: 401). Leaf bases (= segment bases) are slightly contracted. Segment lengths (distance between leaf bases) vary generally from 3 to $12 \mathrm{~mm}$, especially in specimen SM.B 16486 from $7.5-11.5 \mathrm{~mm}$ at the main axis, from 5-10.5 $\mathrm{mm}$ at branchlets of higher orders. This variation of segment length seems to be randomly distributed. Commonly, shorter segments may be recognized near to the bases of branchlets (Fig. 1D). There is a subtle change in diameter of the segments from $6 \mathrm{~mm}$ at the base of the branch to $4 \mathrm{~mm}$ at the very top. In cross section, a segment consists of the thick and fleshy cylindrical leafy part and a woody inner part of only 1-3 mm in diameter (Figs 1C, 5D).

In specimen SM.B 16447 parts of the shoot impression show details of the cellular structure of the epidermis of the segments. Numerous longitudinal rows of stomata are observed by LM. Cellular characters of the stomata are not preserved. In specimen SM.B 16486 the surfaces of the segments show densely arranged, parallel grooves that represent rows of stomata (Fig. 5G). In very few cases the surface of the segments is 

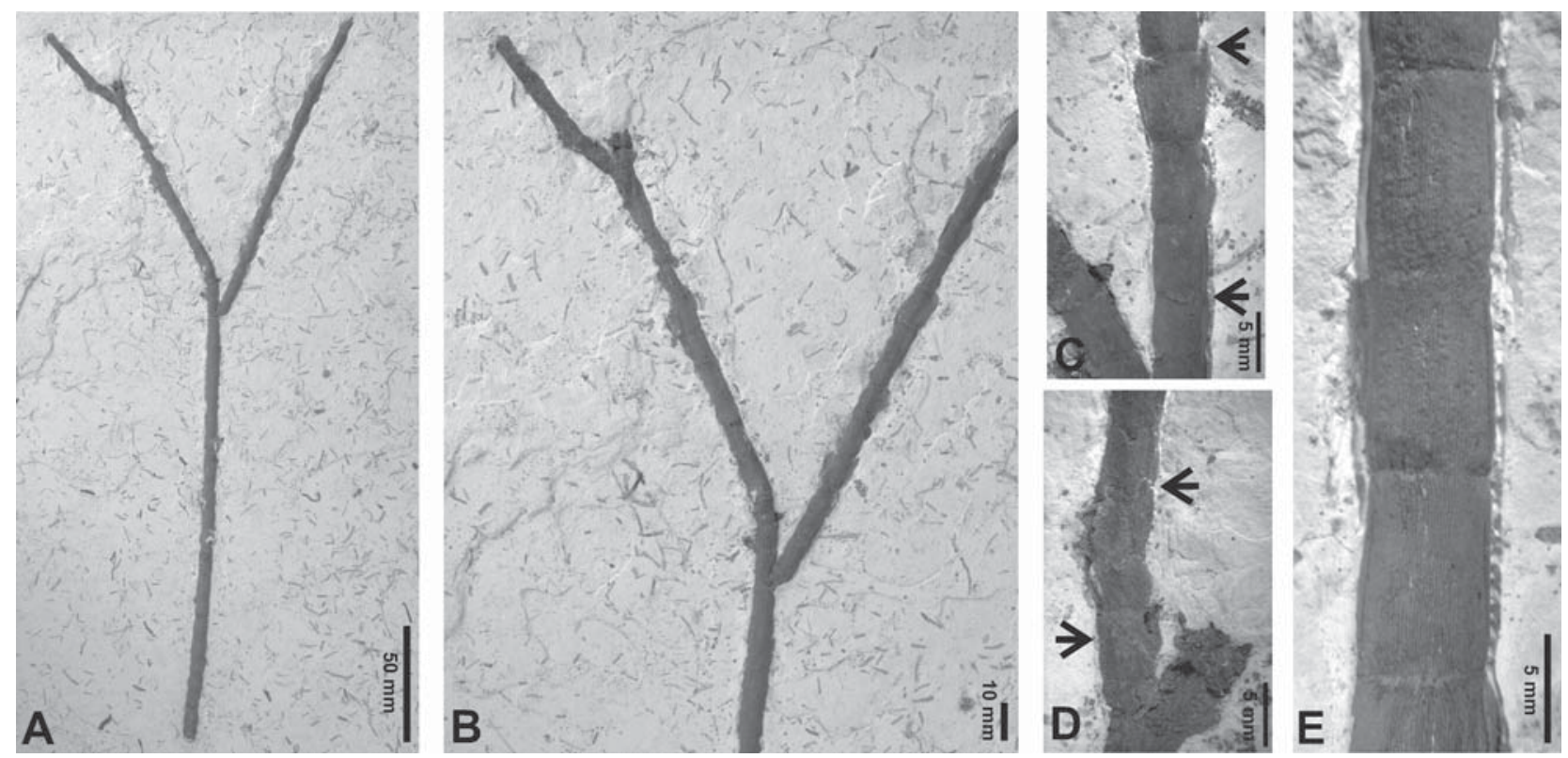

Fig. 4. Frenelopsis sp., leafy shoot, SM.B 16486; A-complete specimen; B - details of A; C-E - few segments of the shoot with dense parallel striation on the surface and with free leaf tips (arrows).

not abraded, thus the cellular structure of the epidermis is visible by LM (Fig. 5E-G). Stomata are arranged in parallel continuous uniseriate rows that densely cover the whole epidermis of the segments. One or two rows of ordinary epidermal cells separate rows of stomata. The stomata are monocyclic or incompletely dicyclic. The orientation of stomatal pori is transverse or oblique to the axis of the segment. The ring of subsidiary cells is oval, with an outer periclinal wall (Florin ring; Fig. 5F), the guard cells are sunken into the epidermis. Ordinary epidermal cells show papillae on the periclinal surfaces (Fig. 5F).

Discussion. The leaf morphology with more than one leaf in a sutureless whorl characterizes the morphogenus Frenelopsis (Watson 1977,
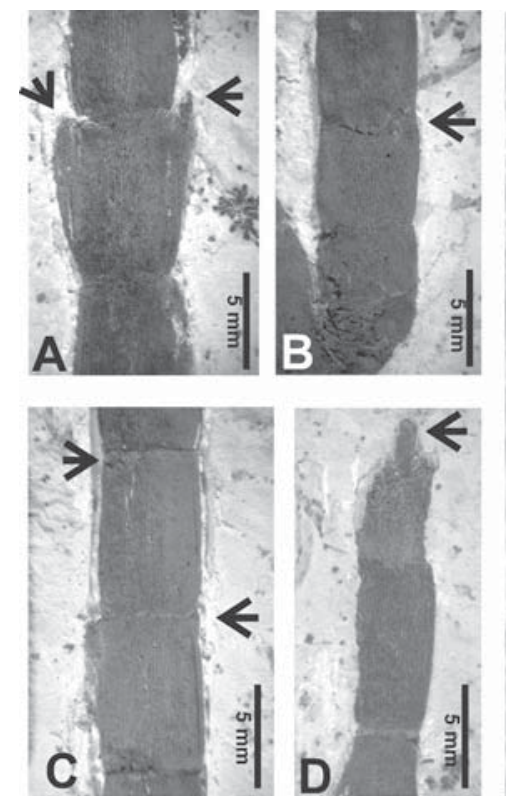
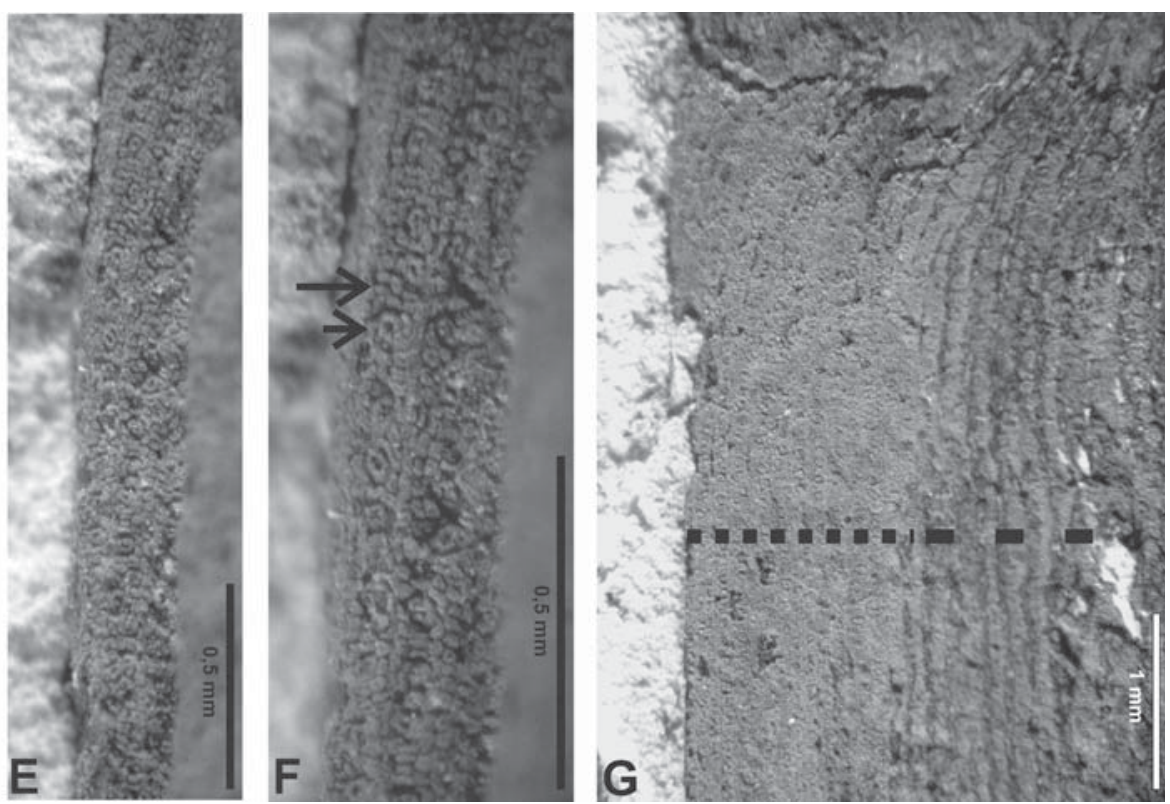

Fig. 5. Frenelopsis sp., leafy shoot, SM.B 16486; A-C - segments of the shoot with dense parallel striation on the surface and with free leaf tips (arrows), A - detail of Fig. 4C, segment with opposite free leaftips; B - detail of Fig. 4C; C - leaftips abraded; D - ultimate branchlet with abraded leaves showing a wide zone of parenchymatous tissue between the wood (arrow) and the epidermis in the segments (= fleshy leaves); $\mathbf{E}$ - part of the epidermis of a cylindrical segment, three longitudinal stomata rows; $\mathbf{F}$ - detail of E, stomata with Florin ring (short arrow), ordinary epidermal cells with papillae (long arrow), oblique orientation of stomata; $\mathbf{G}$ - surface of a segment, preservation of epidermis cells in the left part (dotted line) with dense longitudinal stomata rows, right part with abraded epidermis (broken line). 
1988). Pseudofrenelopsis Nathorst, 1893 emend. Srinivasan, 1995 differs in bearing almost one leaf per whorl and mainly "open" segments with sutures or gaps. The Crato material shows sutureless segments with one or two leaves. If only small sections of the branchlets with only one leaf per segment are available, the determination of the morphogenus is very problematic.

Srinivasan (1995) discussed this problem for material from the early to middle Albian Puddledock locality, USA (Potomac Group). She described shoots with partly opposite-decussate phyllotaxis and partly sections with single-leaved "internodes" with and without sutures, while the stomatal characters are typical for the Pseudofrenelopsis type. Pseudofrenelopsis nathorstiana Srinivasan, 1995 clearly shows that differences in phyllotaxis may no longer provide sufficient grounds for the separation of Frenelopsis and Pseudofrenelopsis (Srinivasan 1995). However, the segments of Frenelopsis are only of the suturless type. Without any formal consequences, Srinivasan (1995) suggested to consider a merger of the morphogenera Frenelopsis and Pseudofrenelopsis.

Frenelopsis consists of several morphospecies typically bearing three leaves per whorl (Kvaček 2000; Watson 1988), but two species have been assigned to Frenelopsis, that show two opposite leaves per whorl and a decussate phyllotaxis. These species are F. teixeirae Alvin \& Pais, 1978 from the Hauterivian to Barremian of Portugal and F. choshiensis Kimura et al., 1985 from the Barremian of Japan (Table 1).

Table 1. Cretaceous species of Frenelopsis Schenk, 1869 and their numbers and arrangements of free leaf tips in comparison with Pseudofrenelopsis Nathorst, 1893.

\begin{tabular}{|c|c|c|c|c|c|}
\hline Species & Occurrence & Stratigraphy & Reference & $\begin{array}{l}\text { Leaves } \\
\text { per segment }\end{array}$ & $\begin{array}{l}\text { Phyllotaxis of free } \\
\text { leaf tips }\end{array}$ \\
\hline $\begin{array}{l}\text { F. alata } \\
\text { (K. Feistmantel, 1881) } \\
\text { Knobloch, } 1971\end{array}$ & $\begin{array}{l}\text { Czech Republik, } \\
\text { France, Portugal }\end{array}$ & $\begin{array}{l}\text { Albian- } \\
\text { Cenomanian } \\
\text { (Turonian) }\end{array}$ & Kvaček 2000 & 3 & $\begin{array}{l}\text { whorls of } 3 \text { in cyclic } \\
\text { arrangement }\end{array}$ \\
\hline $\begin{array}{l}\text { F. harrisii } \\
\text { Doludenko \& } \\
\text { Reymanówna, } 1978\end{array}$ & Tadzikistan & Cenomanian & $\begin{array}{l}\text { Doludenko \& } \\
\text { Reymanowna } 1978\end{array}$ & 3 & $\begin{array}{l}\text { whorls of } 3 \text { in cyclic } \\
\text { arrangement }\end{array}$ \\
\hline $\begin{array}{l}\text { F. hoheneggeri } \\
\text { (Ettingshausen, 1852) } \\
\text { Schenk, } 1869\end{array}$ & $\begin{array}{l}\text { Czech Republic, } \\
\text { Poland }\end{array}$ & Hauterivian & Watson 1988 & 3 & $\begin{array}{l}\text { whorls of } 3 \text { in cyclic } \\
\text { arrangement }\end{array}$ \\
\hline $\begin{array}{l}\text { F. kaneviensis } \\
\text { Barale \& Doludenko, } \\
1985\end{array}$ & Ukraine & Late Albian & $\begin{array}{l}\text { Barale \& } \\
\text { Doludenko } 1985\end{array}$ & 3 & $\begin{array}{l}\text { whorls of } 3 \text { in cyclic } \\
\text { arrangement }\end{array}$ \\
\hline \multirow[t]{2}{*}{$\begin{array}{l}\text { F. occcidentalis } \\
\text { Heer, } 1881\end{array}$} & Portugal & Aptian/Albian & Alvin 1977 & 3 & $\begin{array}{l}\text { whorls of } 3 \text { in cyclic } \\
\text { arrangement }\end{array}$ \\
\hline & NW Germany & Berriasian & $\begin{array}{l}\text { Watson \& Alvin } \\
1999\end{array}$ & 3 & $\begin{array}{l}\text { whorls of } 3 \text { in cyclic } \\
\text { arrangement }\end{array}$ \\
\hline $\begin{array}{l}\text { F. oligostomata } \\
\text { Romariz, } 1946\end{array}$ & Portugal & Cenomanian & Kvaček 2000 & 3 & $\begin{array}{l}\text { whorls of } 3 \text { in cyclic } \\
\text { arrangement }\end{array}$ \\
\hline $\begin{array}{l}\text { F. ramosissima } \\
\text { Fontaine, } 1889\end{array}$ & $\begin{array}{l}\text { Potomac Group } \\
\text { localities, USA }\end{array}$ & $\begin{array}{l}\text { Barremian - } \\
\text { Albian }\end{array}$ & $\begin{array}{l}\text { Axsmith \& Jacobs } \\
2005\end{array}$ & 3 & $\begin{array}{l}\text { whorls of } 3 \text { in cyclic } \\
\text { arrangement }\end{array}$ \\
\hline $\begin{array}{l}\text { F. rubiesensis } \\
\text { Barale, } 1981\end{array}$ & Spain & Berriasian & Barale 1981 & 3 & $\begin{array}{l}\text { whorls of } 3 \text { in cyclic } \\
\text { arrangement }\end{array}$ \\
\hline $\begin{array}{l}\text { F. silfloana } \\
\text { Watson, } 1983\end{array}$ & $\begin{array}{l}\text { Nubian Sandstone, } \\
\text { Sudan }\end{array}$ & Early Cretaceous & Watson 1988 & 3 & $\begin{array}{l}\text { whorls of } 3 \text { in cyclic } \\
\text { arrangement }\end{array}$ \\
\hline $\begin{array}{l}\text { F. teixeirae } \\
\text { Alvin \& País, } 1978\end{array}$ & Portugal & $\begin{array}{l}\text { Hauterive- } \\
\text { Barremian }\end{array}$ & Alvin \& País 1978 & 2 & $\begin{array}{l}\text { opposite pairs in } \\
\text { decussate arrang- } \\
\text { ment }\end{array}$ \\
\hline $\begin{array}{l}\text { F. chochiensis } \\
\text { Kimura et al., } 1985\end{array}$ & Japan & Barremian & Kimura et al. 1985 & 2 & $\begin{array}{l}\text { opposite pairs in } \\
\text { decussate arrang- } \\
\text { ment }\end{array}$ \\
\hline F. $s p$. & $\begin{array}{l}\text { Araripe Basin, NE } \\
\text { Brazil }\end{array}$ & Late Aptian & this paper & 1 or 2 & $\begin{array}{l}\text { partly opposite } \\
\text { pairs }\end{array}$ \\
\hline $\begin{array}{l}\text { Pseudofrenelopsis } \\
\text { Nathorst, } 1893\end{array}$ & $\begin{array}{l}\text { Europe, Asia, Afri- } \\
\text { ca, North America }\end{array}$ & Cretaceous & Watson 1988 & 1 & simple helix \\
\hline $\begin{array}{l}\text { Pseudofrenelopsis } \\
\text { nathorstiana } \\
\text { Srinivasan, } 1995\end{array}$ & Puddledock, USA & $\begin{array}{l}\text { Early/Middle } \\
\text { Albian }\end{array}$ & Srinivasan 1995 & 1 or 2 & $\begin{array}{l}\text { mostly simple } \\
\text { spiral, partly cyclic } \\
\text { arrangment }\end{array}$ \\
\hline
\end{tabular}


Except for Frenelopsis ramosissima Fontaine, 1889 the morphogenera Frenelopsis and Pseudofrenelopsis are distinguished from each other also by stomatal characters. Pseudofrenelopsis shows a papillate Florin ring, the papillae are overhanging the stomatal pits, and Frenelopsis shows nonpapillate Florin rings, but papillae on the subsidiary cells are developed completely down inside the large outer stomatal pit (e.g. Srinivasan 1995; Watson 1988). F. ramosissima bears stomata with papillate Florin rings and no papillae inside the stomatal pit (Watson 1977).

Independent from the ongoing discussion on the concept of the genus Frenelopsis (e.g., Axsmith \& Jacobs 2005; Kvaček 2000), an assignment of the Crato material to this genus on the base on shoot morphology alone appears appropriate. In addition, stomata with nonpapillate Florin rings are mainly characteristic for the genus Frenelopsis. However, any assignment of our material to a distinct species is impossible due to the lack of distinctive epidermal characters, although phyllotaxis shows similarities to F. teixeirae and F. choshiensis. From Pseudofrenelopsis nathorstiana the Crato material differs in bearing only cylindrical sutureless segments.

Palaeobiogeography. Frenelopsis was distributed more or less worldwide during the Early Cretaceous. Species with 3 leaves per whorl are reported from the Early Cretaceous of North America, Europe, Africa and Asia (Table 1).

Frenelopsis species with less than 3 leaves per whorl also appear to be distributed worldwide in the Early Cretaceous: they are known from the Hauterivian to Barremian of Portugal (F.teixeirae Alvin \& Pais, 1978), from the Barremian of Japan (F. choshiensis Kimura et al., 1985) and now also from the Aptian of Brazil. The occurrence of Frenelopsis in South America at the time when the Gondwana continents had just started to drift apart in the Early Cretaceous is not unexpected.

A worldwide distribution in the Early Cretaceous is also recorded for Pseudofrenelopsis (North America, Srinivasan 1995; Africa, Watson 1983; Europe, Central America, Watson 1977; Asia, Mussa et al. 1991 and Zhou Zhiyan 1995).

\section{Taphonomy, palaeoecology and palaeogeobotany}

Many of the conifer specimens from the Crato Formation are relatively fragmentary and partly abraded. This seems also to be the case with
Tomaxellia biforme of which only two relatively small pieces have been observed in various collections among several hundred fossils. Therefore, we assume that the majority of the Tomaxellia biforme plants did not grow close to the area of deposition and the plant fragments were transported by rivers.

Due to their fragility (SM.B 16448; Fig. 3A), large, almost completely preserved shoots of Frenelopsis sp., most likely were not transported over long distances. This genus might have grown near the place of deposition and thus its habitat was probably under a brackish influence of a hypothesized lagoon (Martill et al. 1993).

There is no indication that these frenelopsid plants were shrubs or large trees. An occurrence of frenelopsids in a monospecific or low diversity assemblage, as known from other localities (e.g., Axsmith \& Jacobs 2005), can be excluded for the Crato flora because of its rarity in the respective taphocoenoses.

All conifer taxa encountered at the Crato locality, including Tomaxellia biforme, bear rather thick, coriaceous leaves. In Frenelopsis sp. the wide zone of parenchymatous tissue between the wood and the epidermis in the segments of ultimate vegetative shoots ("fleshy leaf"; Fig. 5D) possibly indicates succulence (e.g., Axsmith \& Jacobs 2005). However, the common interpretation of frenelopsids as arid coastal forest-inhabiting xerophytes (Vakhrameev 1970) was modified by Gomez et al. (2002). They asserted that the frenelopsids were adapted to a wider ecological range and thus habitats of different species might have varied substantially. Axsmith \& Jacobs (2005) conclude for F. ramosissima found at sites in the Texas and the Potomac Group (USA) that some species may have had also exhibited large ecological amplitudes. However, due to the lack of a palaeosociological concept for the Crato flora and the sparse record of Frenelopsis sp. within the flora the palaeoecological interpretation of the Crato frenelopsids remains vague.

A warm to hot, temporarily dry (possibly seasonally dry) climate during the late Early Cretaceous in the palaeoequatorial region has been hypothesized by various authors (e.g. Skelton 2003). For the Crato region this assumption is validated by various plant groups. Ferns, several gymno- and angiosperms show adaptations to drought, such as spines and coriaceous and/or reduced leaves (Mohr \& Rydin 2002; Mohr \& Bernardes-de-Oliveira 2004). Some of the characters of the Crato conifers, such as coriaceous leaves and thick cuticles as well as succulent 
twigs in Frenelopsis sp., also support this assumption.

It is worth mentioning that a flora of the same age from Tunisia shares several taxa with the Crato flora, among them Podozamites and various angiosperms, such as Trifurcatia Mohr \& Rydin, 2002 and nymphaealean waterplants (Barale \& Ouaja 2001; Mohr et al. in press). The flora of the Early Cretaceous of Portugal also shares several taxa with the Crato flora, among them the conifers Brachyphyllum obesum, Podozamites sp. and Frenelopsis teixeirae, a Frenelopsis-type with less than 3 leaves per whorl (Teixeira 1948). The flora of the Leiva region in Colombia (Aptian, Early Cretaceous) contains also conifers of the Brachyphyllum- and the Podozamites-morphotype and female cones of Araucariaceae (Van Waveren et al. 2002).

Most of the conifer families of early to midCretaceous floras such as Araucariaceae and Cheirolepidiaceae seem to have been relatively widely distributed. This is due to the fact that palaeofloristic exchange between Gondwana (South America, Africa, Australia) and the Northern Hemisphere (North America, Europe, Asia) was possible during the Jurassic, perhaps until the Early Cretaceous. However, endemic taxa and/or typical groups of conifers, characteristic for a region or a continent, seem to have existed as well. Tomaxellia, most likely endemic to South America, did not reach Africa or Europe during the Early Cretaceous. This might imply a relatively late evolution of the genus during the latest Jurassic/earliest Cretaceous, when the successive opening of the Atlantic made migrations much more difficult.

\section{Conclusions}

Cheirolepidiaceous conifers from the Crato Formation (late Aptian, Early Cretaceous) of northeastern Brazil were studied. The material consists of sterile leafy shoots that are partly well preserved. Two genera were recognized based on morphological and anatomical characters, Frenelopsis and Tomaxellia, the latter known previously only from Patagonia, Argentina. Detailed investigations of the leaf epidermis of Tomaxellia biforme were carried out by using the scanning electron microscope (SEM). The leaf epidermis of Frenelopsis sp. was studied by light microscope (LM). Frenelopsis sp. might have grown near the Crato-lagoon/lake under brackish influence. The palaeoecology of Tomaxellia biforme remains unresolved. Its habitat might have been relatively far from the locality of deposition due to its rare occurrence and fragmentary preservation. The morphological and anatomical characters of both conifers are interpreted as adaptations to a warm and temporarily dry climate.

\section{Acknowledgements}

We are especially indebted to Dr. H.-U. Schenker (Kirchhain) for his kindly and steady support of our studies. Thanks to Carola Kunzmann (Museum für Mineralogie und Geologie, Dresden) for preparation for SEM studies. The technical support was provided by Gabriela Drescher (MfN, Berlin) who assisted the SEM preparations and helped with the SEM pictures, and by Carola Radke (MfN, Berlin) and Barbara Bastian (MMG, Dresden) who took some of the photographs of the fossils. Dr. David Lazarus (MfN, Berlin) was so friendly to check the English version of the manuscript. We are also thankful to Prof. Dr. Johanna Van Konijenburg-Van Cittert (Utrecht, Leiden) and to Dr. Jiři Kvaček (Prag) for their critical comments.

\section{References}

Alvin, K. L. 1977. The conifers Frenelopsis and Manica in the Cretaceous of Portugal. - Palaeontology 20: 387-404.

- 1982. Cheirolepidiaceae: Biology, structure and palecology. - Review of Palaeobotany and Palynology 37: 71-98.

Alvin, K. L., Spicer, R. A. \& Watson, J. 1978. A Classopolliscontaining male cone associated with Pseudofrenelopsis. Palaeontology 21: 847-856.

Alvin, K. L. \& Pais, J. J. C. 1978. A Frenelopsis with opposite decussate leaves from the Lower Cretaceous of Portugal. - Palaeontology 21: 873-879.

Arai, M., Coimbra, J. C. \& Silva-Teles, A. C. 2001. Síntese bioestratigráfica da Bacia do Araripe (nordeste do Brasil). In Barros, L. M., Nuvens, P. C., Figueira Coleçao J. B. M. (Eds.), Chapada do Araripe: 109-117, Crato.

Archangelsky, S. 1963. A new Mesozoic flora from Ticó, Santa Cruz Province, Argentina. - Bulletin of the British Museum (Natural History) Geology 8 (2): 47-92.

- 1966. New gymnosperms from the Ticó Flora, Santa Cruz Province, Argentina. - Bulletin of the British Museum (Natural History) Geology 13 (5): 259-295.

- 1968. On the genus Tomaxellia (Coniferae) from the Lower Cretaceous of Patagonia (Argentina) and its male and female cones. - Journal of the Linnean Society London Botany 61: 153-165.

- 1994. Comparative ultrastructure of three Early Cretaceous gymnosperm pollen grains: Araucariacites, Balmeiopsis and Callialasporites. - Review of Palaeobotany and Palynology 83: 185-198.

Archangelsky, S. \& Gamerro, J. C. 1968. Pollen grains found in coniferous cones from the Lower Cretaceous of Patagonia (Argentina). - Review of Palaeobotany and Palynology 5: 179-182.

Archangelsky, S. \& Taylor, T. N. 1986. Ultrastructural studies of fossil plant cuticles, II. Tarphyderma gen. n., a Cretaceous conifer from Argentina. - American Journal of Botany 73: $1577-1587$.

- 1991. Tarphyderma punctatum (Michael) Archangelsky \& Taylor, comb. nov., an Early Cretaceous conifer. - Taxon 40 (2): $319-320$. 
Axsmith, B. J. \& Jacobs, B. F. 2005. The conifer Frenelopsis ramosissima (Cheirolepidiaceae) in the Lower Cretaceous of Texas: systematic, biogeographical, and paleoecological implications. - International Journal of Plant Science 166 (2): 327-337.

Axsmith, B. J., Krings, M. \& Waselkow, K. 2004. Conifer pollen cones from the Cretaceous of Arkansas: implications for diversity and reproduction in Cheirolepidiaceae. Journal of Paleontology 78 (2): 402-409.

Barale, G. 1981. La paléoflore jurassique du Jura français. Documents des laboratoires de géologie Lyon 81: 1-467.

Barale, G. \& Doludenko, M. P. 1985. Une nouvelle espèce de Cheirolepidiaceae de l'Albien supérieur d'URSS: Frenelopsis kaneviensis nov. sp. - Comptes Rendus 100. Congrès National des Sociétés Savantes (Montpellier 1985) 5: 99-114.

Barale, G. \& Ouaja, M. 2001. Découverte de nouvelles flores avec des restes à affinités angiospermiennes dans le Crétacé inférieur du Sud Tunesien. - Cretaceous Research 22: $131-143$.

Barreto, A. M. F., Bernardes-de-Oliveira, M. E. C., Dilcher, D. A., Mandarim-de-Lacerda, A. F. \& Viana, M. S. S. 2000. Early Cretaceous monocarpelar fruit of the Crato Member, Santana Formation, Araripe Basin, Northeastern Brazil. - Revista Universidade Guarulhos, Geociencias 5: 121-124.

Bernardes-de-Oliveira, M. E. C., Barreto, A. M., Dilcher, D. A. \& Mandarim-de-Lacerda, A. F. 2003. Isoetes eocretáceo do Membro Crato, Formação Santana, Bacia do Araripe, Nordeste do Brasil. - 18. Congresso Brasileiro de Paleontologia 2003 Brasília (DF): 68-69.

Bernardes-de-Oliveira, M. E. C., Lima, M. R. \& Pons, D. 1993. Folhas de Araucariaceae da Formação Santana, Cretáceo do Nordeste Brasileiro. - Anais Academia Brasileira de Ciências Resumos Comunicações São Paulo 65: 329-330.

Bernardes-de-Oliveira, M. E. C., Mohr, B. A. R., Kunzmann, L., Franca-Barreto, A. M., Castro-Fernandes, M. C., Sucerquia, P. A. \& Andrade, A. F. G. 2005. Conífera Frenelopsida (Cheirolepidiaceae), presente no Membro Romualdo, Formação Santana, Albo-Aptiano da bacia do Araripe, NE do Brasil. - XIX Congresso Brasileiro de Paleontologia/VI Congresso Latino-Americano de $\mathrm{Pa}$ leontologia, SBP, Aracaju (SE), Resumos, Digital Publication.

Bernardes-de-Oliveira, M. E. C., Rabelo-Leite, F. R., RicardiBranco, F. \& Mandarim-de-Lacerda, A. F. 1999. Esquizeacea da Formação Santana, Eocretáceo da Bacia do Araripe, Nordeste do Brazil. - 16. Congresso Brasileiro de Paleontologia Boletim de Resumos: 26-27.

Braun, C. F. W. 1843. Beiträge zur Urgeschichte der Pflanzen. In Münster, G. Graf zu (ed.). Beiträge zur Petrefactenkunde 6: 1-46, Bayreuth.

Calder, M. G. 1953. A coniferous petrified forest in Patagonia. - Bulletin of the British Museum (Natural History) Geology 2: 97-140.

Cantrill, D. J. \& Falcon-Lang, H. J. 2001. Cretaceous (late Albian) coniferales of Alexander Island, Antarctica. 2. Leaves, reproductive structures and roots. - Review of Palaeobotany and Palynology 115: 119-145.

Dilcher, D. A., Bernardes-de-Oliveira, M. E. C., Pons, D. \& Lott, T. A. 2005. Welwitschiaceae from the Lower Cretaceous of Northeastern Brazil. - American Journal of Botany 92 (8): 1294-1310.

Doludenko, M. P. 1978. Frenelopsis (Coniferales) genus and the first findings of its generic types in the Cretaceous deposits of the USSR. - Palaeontological Journal 1978 (3): 107-121.

Doludenko, M. P. \& Reymanowna, M. 1978. Frenelopsis harrisii sp. nov. from the Cretaceous of Tajikistan, URSS. Acta Palaeobotanica 19 (1): 3-12.

Doyle, J. A. 1992. Revised palynological correlations of the lower Potomac Group (U.S.A.) and the Cocobeach se- quence of Gabon (Barremian-Aptian). - Cretaceous Research 13: 337-349.

Duarte, L. 1985. Vegetais fósseis da Chapada do Araripe, Brasil. - Coletânea de Trabalhos Paleontológicos do 8. Congresso Brasileiro de Paleontologia 1983 Paleontologia e Estratigrafia 2: 557-563.

- 1993. Restos de Araucariáceas da Formação SantanaMembro Crato (Aptiano), NE do Brasil. - Anais Academia Brasileira de Ciências 65 (4): 357-362.

Endlicher, S. 1847. Synopsis coniferarum. 368 pp., Apud Scheitlin \& Zollikofer, St. Gallen.

Ettingshausen, C. v. 1852. Beitrag zur näheren Kenntnis der Flora der Wealdenperiode. - Abhandlungen der Kaiserlich-königlichen Geologischen Reichsanstalt Wien 1 (2/3): $1-32$.

Falcon-Lang, H. J. \& Cantrill, D. J. 2000. Cretaceous (late Albian) coniferales of Alexander Island, Antarctica: Wood taxonomy: a quantitative approach. - Review of Palaeobotany and Palynology 111: 1-17.

Feistmantel, K. 1881. Der Hangendflötzung im Schlan-Rakonitzer Steinkohlenbecken. - Archiv der Naturwissenschaftlichen Landesdurchforschung Böhmens 4 (6): $1-112$.

Fontaine, W. M. 1889. The Potomac or younger Mesozoic flora. - Monographs of the U.S. Geologic Survey 15: $1-377$.

Francis, J. E. 1983. The dominant conifer of the Jurassic Purbeck Formation, England. - Palaeontology 26 (2): 277-294.

Gomez, B. C., Martin-Closas, C., Barale, G., Solé de Porta, N., Thévenard, F. \& Guigrard, G. 2002. Frenelopsis (Coniferales: Cheirolepidiaceae) and related male organs from the Lower Cretaceous of Spain. - Palaeontology 45: 997-1036.

Harris, T. M. 1979. The Yorkshire Jurassic Flora, V. Coniferales. 166 pp., British Museum (Natural History), London.

Heer, O. 1881. Contributions à la flore fossile du Portugal. Comunicações Trabalhos Serviço Geologia Portugal Serie 4: $i-x i v+1-51$.

Henkel, J. B. \& Hochstetter, H. W. 1865. Synopsis der Nadelhölzer, deren charakteristische Merkmale nebst Andeutungen über ihre Cultur und Ausdauer in Deutschlands Klima. 446 pp., Cotta, Stuttgart.

Hollick, A. \& Jeffrey, E. C. 1909. Studies of Cretaceous coniferous remains from Kreischerville, New York. - Memories of New York Botanical Garden 3: 1-76.

Jung, W. 1968. Hirmerella münsteri (Schenk) Jung nov. comb., eine bedeutsame Konifere des Mesozoikums. - Palaeontographica B 122: 55-93.

Kimura, T., Saiki, K. \& Arai, T. 1985. Frenelopsis choshiensis sp. nov., a Cheirolepidiaceous conifer from the Lower Cretaceous Choshi Group in the Outer Zone of Japan. - Proceedings of the Japanese Academy B 61: 426-429.

Knobloch, E. 1971. Neue Pflanzenfunde aus dem böhmischen und mährischen Cenoman. - Neues Jahrbuch für Geologie und Paläontologie, Abhandlungen 139 (1): 43-56.

Kunzmann, L., Mohr, B. A. R. \& Bernardes-de-Oliveira, M. E. C. 2004. Gymnosperms from the Lower Cretaceous Crato Formation (Brazil). I. Araucariaceae and Lindleycladus (incertae sedis). - Mitteilungen des Museums für Naturkunde Berlin, Geowissenschaftliche Reihe 7: 155-174.

Kvaček, J. 2000. Frenelopsis alata and its microsporangiate and ovuliferous reproductive structures from the Cenomanian of Bohemia (Czech Republic, Central Europe). Review of Palaeobotany and Palynology 112: 51-78.

Leme, E. M. C., Brown, G. K., Dilcher, D., Bernardes-de-Oliveira, M. E. C., Siqueira, J. A. \& Sales, A. M. F. 2005. Protananaceae, a new fossil monocot family from the Lower Cretaceous, Santana Formation, northeastern Brazil. In Botany Conference of Austin, Texas, 13-17/08/ 2005 - CD-ROM. 
Lindley, J. \& Hutton, W. 1836. The fossil flora of Great Britain; or, figures and descriptions of the vegetable remains found in a fossil state in this country, part 3. 208 pp., pls. 157-230, London.

Lima, M. R. de 1978. Palinologia da Formação Santana (Cretáceo do Nordeste do Brasil). I. Introdução geológica e descrição sistemática dos esporos da Subturma Azonotriletes. - Ameghiniana 15: 333-365.

- 1979. Palinologia da Formação Santana (Cretáceo do Nordeste do Brasil). II. Descrição sistemática dos esporos da Subturma Zonotriletes e Turma Monoletes, e dos polens das Turmas Saccites a Aletes. - Ameghiniana 16: $27-63$.

Linder Dutra, T. L., Rockenbach Boardman, D. \& SouzaLima, W. 2002. Os fosseis da bacia de Sergipe-Alagoas. 1. Os vegetais: as gimnospermas. - Phoenix 4 (46): 1-8.

Maisey, J. G. 1991. Santana fossils. An illustrated Atlas. 459 pp., TFH Publications, Neptune City, New Jersey.

Martill, D. M., Brito, P. M., Wenz, M. \& Wilby, P. R. 1993. Fossils of the Santana and Crato Formations, Brazil. In Jarzembowski, E. A. (ed.). Palaeontological Association Field Guides to Fossils Series 5: 1-159, The Palaeontological Association, London.

Martill, D. M., Loveridge, R. F., Gomes de Andrade, J. A. F. \& Cardoso, A. H. 2005. An unusual occurrence of amber in laminated limestones: the Crato Formation Lagerstätte (Early Cretaceous) of Brazil. - Palaeontology 48 (6): 1399-1408.

Mohr, B. A. R. \& Bernardes-de-Oliveira, M. E. C. 2004. Endressinia brasiliana, a magnolialean angiosperm from the Lower Cretaceous Crato Formation (Brazil). - International Journal of Plant Sciences 165 (6): 1121-1133.

Mohr, B. A. R.; Bernardes-de-Oliveira, M. E. C., Barreto, A. M. F. \& Castro-Fernandes, M. C. 2004. Gnetophyta preservation and diversity in the Early Cretaceous Crato Formation (Brazil). - 7. International Organization of Paleobotany Conference Bariloche Argentina Abstracts: 81.

Mohr, B. A. R., Bernardes-de-Oliveira, M. E. C., Barale, G. \& Ouaja, M. in press. Palaeogeographic distribution and ecology of a basal angiosperm, Trifurcatia chofatii (Saporta sensu Teixeira) n. comb., during the Aptian of northern Gondwana and southern Laurasia. - Cretaceous Research.

Mohr, B. A. R. \& Eklund, H. 2003. Araripia florifera, a magnoliid angiosperm from the Lower Cretaceous Crato Formation (Brazil). - Review of Palaeobotany and Palynology 126: $279-292$.

Mohr, B. A. R. \& Friis, E. M. 2000. Early angiosperms from the Lower Cretaceous Crato Formation (Brazil), a preliminary report. - International Journal of Plant Sciences 161: $155-167$.

Mohr, B. A. R. \& Gee, C. T. 1992. An early Albian palynoflora from the Kerguelen Plateau, southern Indian Ocean (Leg 120). - Proceedings of the Ocean Drilling Program Scientific Results 120: 255-271.

Mohr, B. A. R. \& Rydin, C. 2002. Trifurcatia flabellata n. gen. n. sp., a putative monocotyledon angiosperm from the Lower Cretaceous Crato Formation (Brazil). Mitteilungen aus dem Museum für Naturkunde in Berlin, Geowissenschaftliche Reihe 5: 335-344.

Mussa, D., Bernardes-de-Oliveira, M. E. C., Dino, R. \& Arai, M. 1991. A presença do gênero Pseudofrenelopsis Nathorst da bacia mesozóica de Lima Campos, Estado do Ceará, Brasil. - 12. Congresso Brasileiro de Paleontologia Resumos São Paulo: 115.

Nathorst, A. G. 1893. Pflanzenreste aus dem Neokom von Tlaxiaco. In Felix, J., Lenk, H. (eds). Beiträge zur Geologie und Paläontologie der Republik Mexico, Teil 2: 51-54, Schweizerbart, Leipzig, Stuttgart.

Neumann, V. H. N. L. \& Cabrera, L. 1999. Una nueva propuesta estratigraphica para la tectono secuencia post-rifte de la cuenca de Araripe, noreste de Brasil. In Dias-Brito, D., Castro, J. C., Rohn, R. (eds). Boletim do $5^{\circ}$ Simpósio sobre o Cretáceo do Brasil e $1^{\circ}$ Simpósio sobre el Cretácico de América del Sur. - UNESP Serra Negra (SP): 279-285.

Osborn J. M., Taylor, T. N. \& Lima, M. R. de 1993. The ultrastructure of fossil ephedroid pollen with gnetalean affinities from the Lower Cretaceous of Brazil. - Review of Palaeobotany and Palynology 77: 171-184.

Pflug, H. D. 1953. Zur Entstehung und Entwicklung des angiospermiden Pollens in der Erdgeschichte. - Palaeontographica B 95: 60-171.

Pons, D. B. 1988. Le Mésozoque de Colombie. Macroflores et microflores. - Cahiers de Paléontologie. Editions du Centre National de la Recherche Scientifique, 168 pp., Paris.

Pons, D. B., Berthou, P. Y., Melo-Filgueiras, J. B. \& Alcantara-Sampaio, J. J. 1996. Palynologie des unités "Fundão", "Crato", et "Ipubi" (Aptien supérieur à Albien inférieur - moyen, bassin d'Araripe, nordest du Brésil): enseignements paléoécologiques, stratigraphiques et climatologiques. - Géologie de l'Afrique et de L'Atlantique Sud: Acta Colloques Angers 1994: 383-401.

Regali, M. S. P. 1989. A idade dos evaporitos da plataforma continental do Ceará, Brasil, e sua relação com os outros evaporitos das bacias nordestinas. In Oliveira-Babinski, M. E. C. B. (ed.). Paleobotânica e palinologia na América do Sul, VI Reunião de Paleobotânicos e Palinólogos, 1987. - Boletim IG-USP, Publicação Especial, Instituto de Geociências, Universidade de São Paulo 7: 139-143.

Romariz, C. 1946. Estudo e revisão das formas portugesas de Frenelopsis. - Boletim Museu Laboratorio Mineralógico Geológico Universidade Lisboa 14 (4): 135-150.

Rydin, C., Mohr, B. A. R. \& Friis, E. M. 2003. Cratonia cotyledon gen. et sp. nov.: a unique Cretaceous seedling related to Welwitschia. - Proceedings of the Royal Society, London B (Supplement) Biology Letters 270: 1-4.

Schenk, A. 1869. Beiträge zur Flora der Vorwelt. 3. Die fossilen Pflanzen der Wernsdorfer Schichten in den Nordkarpathen. - Palaeontographica 19: 1-34.

Seward, A. C. 1919. Fossil plants, a text-book for students of botany and geology, Vol. IV: Ginkgoales, Coniferales, Gnetales. 543 pp., Cambridge University Press, Cambridge UK.

Skelton, P. W. (ed.) 2003. The Cretaceous World. 360 pp. The Open University, Cambridge University Press, Cambridge.

Spegazzini, C. 1924. Coniferales fosiles Patagonicas. - Anales de la Sociedad Cientifica de Argentina 98: 125-139.

Spicer, R. A., McRees, P. A. \& Chapman J. L. 1994. Cretaceous phytogeography and climate signals. In Allen, J. R. L., Hoskins, B. J., Sellwood, B. W., Spicer, R. A., Valdes, P. J. (eds.). Palaeoclimates and their Modelling: 69-78, The Royal Society, Chapman \& Hall, London.

Srinivasan, V. 1995. Conifers from the Puddledock locality (Potomac group, Early Cretaceous) in eastern North America. - Review of Palaeobotany and Palynology 89: 257-286.

Teixeira, C. 1948. Flora Mesozoica Portuguesa. 118 pp., Servicios Geologicos de Portugal, Lisboa.

Traverse, A. 2004. Proposal to conserve the fossil pollen morphogeneric name Classopollis against Corollina and Circulina. - Taxon 53 (3): 847-848.

Vakhrameev, V. A. 1970. Range and palaeoecology of Mesozoic conifers, the Cheirolepidiaceae. - Paleontologicheskyi Zhournal 1: 19-24.

Van der Ham, R. W. J. M., Van Konijnenburg-Van Cittert, J. H. A., Dortangs, G. F. W. \& Van der Burgh, J. 2003. Brachyphyllum patens (Miquel) comb. nov. (Cheirolepidiaceae?): remarkable conifer foliage from the Maastrichtian type area (Late Cretaceous, NE Belgium, SE Netherlands). - Review of Palaeobotany and Palynology 127: $77-97$.

Van Waveren, I. M., Van Konijenburg-Van Cittert, J. H. A., Van der Burgh, J. \& Dilcher, D. L. 2002. Macrofloral re- 
mains from the Lower Cretaceous of the Leiva region (Colombia). - Scripta Geologica 123: 1-39.

Watson, J. 1977. Some Lower Cretaceous conifers of the Cheirolepidiaceae from the U.S.A. and England. Palaeontology 20 (4): 715-749.

- 1983. A new species of the conifer Frenelopsis from the Cretaceous of Sudan. - Botanical Journal of the Linnean Society London 86: 161-167.

- 1988. The Cheirolepidiaceae. In Beck, C. B. (ed.). Origin and Evolution of Gymnosperms: 382-447, Columbia University Press, New York.
Watson, J. \& Alvin, K. L. 1999. The cheirolepidiaceous conifers Frenelopsis occidentalis Heer and Watsoniocladus valdensis (Seward) in the Wealden of Germany. - Cretaceous Research 20: 315-326.

Watson, J. \& Fisher, H. 1984. A new conifer genus from the Lower Cretaceous Glen Pose Formation, Texas. - Palaeontology 27: 718-727.

Zhou Zhiyan 1995. On some Cretaceous Pseudofrenelopsids with a brief review of cheirolepidiacous conifers in China. - Review of Palaeobotany and Palynology 84: 419-438. 